\title{
Economics of Water Yam (Dioscorea alata) Production in South Eastern Nigeria
}

\author{
"Nwike, M. C. ${ }^{1}$ OKoli, T.O. ${ }^{1}$ Ugwumba, C.O.A ${ }^{2}$ \\ ${ }^{I}$ Department of Agricultural Science Education, Federal College of Education (Technical), Umunze Anambra \\ State, Nigeria \\ ${ }^{2}$ Department of Agricultural Economics and Extension Chukwuemeka Odumegwu Ojukwu University Igbariam \\ Campus, Anambra State Nigeria. \\ Corresponding Author: Nwike, M. C
}

\begin{abstract}
The decreasing trend in acceptability, yield and income realized from water yam (Dioscorea alata) production in South Eastern Nigeria informed this study. It specifically examined respondents enterprise profitability, the socio-economic determinants of output, production system and constraints to production. Multi-stage and random sampling procedure were used in selecting 120 respondents from three of the five states in the region. Pre-tested questionnaire was used as instrument for data collection while descriptive statistics, enterprise budgeting and multiple regression were used for data analysis. Findings showed that majority (67\%) of the respondents were males, $75 \%$ were married with mean household size of 5 persons and mean educational attainment of 8 years. Farming systems adopted by the farmers included mixed and continuous cropping, and farm sizes of less than one hectare. Output was significantly and positively determined by educational level, gender, farm size, cost of inputs, number of extension visits and amount of credit obtained. The enterprise was profitable judging by the positive values of gross margin, net farm income, mean net farm income and net return

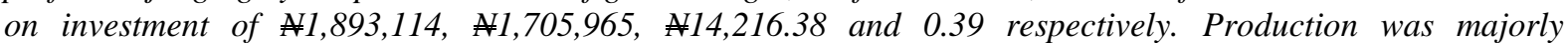
constrained by high cost of labour, low acceptability and demand of product, lack of improved varieties as well as poor technical know-how. Research institutes should focus efforts on upgrading the yield and quality of the variety while government provides enabling incentives to the extension agencies and farmers, to enhance their outputs and ensure improvement in product supply and acceptability.
\end{abstract}

Keywords: Economics, production, south eastern Nigeria, water Yam,.

\section{Introduction}

Yam (Dioscorea spp.) is an annual tuber and monocot plant of the genus Dioscorea and family dioscoreacea, grown mainly for its edible starchy tubers. Only ten out of the 600 classified species are used as food. In West Africa, the six most commonly grown varieties are white yam D. rotundata, water yam (D. alata), yellow yam D. cayenensis, aerial yam D. bulbifera, Chinese yam D. esculenta and trifoliate yam D. dumentorum (Babalaye, 2005). Nigeria is the world leading producer of yam with a 2012 estimated output figure of 48 million metric tonnes. Southeast Nigeria produced 11.16 million tones representing about 23 percent of the national output (Federal Ministry of Agriculture and Rural Development (FMARD) and National Agricultural Extension and Research Liaison Services (NAERLS), 2014).In Nigeria, white yam D. rotundata is the most popularly grown and consumed variety accounting for over 70 percent of total production.

Water yam (D. alata) is another important species of the dioscoreacea family grown in some parts of Nigeria for its large roots with fine edible white fleshes. A native of Southeast Asia, the specie is less popular than white yam in Nigeria. It seems unnoticed when compared to other varieties of yam and is often regarded as food for the poor (Agwu and Avoaja, 2012). It therefore plays very minor role in both local and international yam trade. These misconceptions have contributed to its dwindling popularity in the country despite its overwhelming nutritional and health benefits. According to Wireko-Manu Ibok, Elis, Asiedu and Maziya-Dixon (2013), water yam contains high level of Total Dietary Fibre (TDF) which makes it suitable for management of pile, constipation and diabetes. It is also rich in Vitamin $\mathrm{C}$, beta carotene, vitamin $\mathrm{E}$, calcium, potassium, magnesium, copper and antioxidants. These nutrients are known to play vital role in general body upkeep as well as immune functioning, wound healing, suppression of blood sugar, bone growth and anti-ageing.

Also according to Agwu and Avoaja (2012) water yam is a good source of vitamin $\mathrm{B}_{6}$ which is needed in the body to breakdown substances called homcystein which can directly damage blood vessel walls, hence reducing the risk of heart disease. Common recipes made from water yam in Nigeria include porridge, yam fritters, pounded yam fufu, yam balls, grated water yams and yam mixed with vegetables (All Nigerian Recipes, 
2014).Inspite of the high nutritional and health benefits of water yam, little attention is paid to the biology and economics of its production, as past studies focused mainly on white yam. The declining production level of water yam may not be unconnected with its poor taste and size, poor market price, and difficult production system. This therefore necessitated the conduct of the study aimed at examining the economics of water yam production is South Eastern Nigeria. Specifically the study identified the socio-economic characteristics of producers; examined enterprise profitability, effect of socio-economic characteristics of respondents on output level, production systems adopted by the farmers and constraints to water yam production in the area.

\section{Methodology}

South Eastern Nigeria is one of the six geopolitical zones in the country. It comprises of five states namely Abia, Anambra, Ebonyi, Enugu and Imo. The area lies between longitude $7^{0} 22^{\prime}-7^{0} 30^{\prime}$ East and latitude $5^{0} 7^{\prime}-6^{0} 27^{\prime}$ North of equator. It has a projected population of about 42 million people and land mass of $32,610 \mathrm{~km}^{2}$ The climate is tropical with vegetation typical of rainforest zone of West Africa. Farming is a major occupation of the people with key arable crops comprising of maize, yam, cassava, cocoyam and rice. Multi-stage and random sampling procedures were adopted in selecting respondents. At stage I, simple random sampling technique of balloting was used in selecting three out of the five states namely Abia, Anambra and Imo. At stage II, two Local Government Areas (LGAs) were each selected from the three states bringing the number of LGAs to six. Two communities were randomly selected from the six LGAs in stage III bringing the total number of communities to twelve. The final stage involved random selection of 10 water yam famers from each of the sampled communities giving a sample size of 120. A 26 item structured questionnaire was used to obtain data on the respondents' socio-economic characteristics of age, gender, educational level, farming experiences, farm size, household size, marital status, amount of credit obtained and number of extension visits. Data were also collected on the faming system of water yam producers, revenue and production variables as well as constraints to water yam production in the 2015 production season. The data were analyzed using descriptive and inferential statistics. The descriptive statistics used to analyze the socio-economic characteristics of the farmers, farmers production system and constraints to production were frequency distribution, percentage and mean, while regression model of the double log form was used to estimate determinants of water yam production output in the study area.

Analytical Model

The regression model is expressed implicitly as: $Z_{1}=\beta_{0}+\beta_{1} X_{1}+\beta_{2} X_{2}+\beta_{3} X_{3}+\beta_{4} X_{4}+\beta_{5} X_{5}+\beta_{6} X_{6}+\beta_{7} X_{7}+$ $\beta_{8} X_{8}+\beta_{9} X_{9}+e$.

Where

$\mathrm{Z}_{1}=$ Production output $(\mathrm{kg})$

$\mathrm{B}_{0}=$ Constant term

$\mathrm{X}_{1}=$ Age of water yam farmers (years)

$\mathrm{X}_{2}=$ Gender (dummy: male $=1$, female $=2$ )

$\mathrm{X}_{3}=$ Educational level (years)

$\mathrm{X}_{4}=$ Farming experience (years)

$\mathrm{X}_{5}=$ Farm size (ha)

$\mathrm{X}_{6}=$ Marital status (dummy: married $=1$, single $=2$ )

$\mathrm{X}_{7}=$ Amount of credit obtained ( $\left.\mathrm{N}\right)$

$\mathrm{X}_{8}=$ Number of extension visits

$\mathrm{X}_{9}=$ Cost of production inputs ( $\mathrm{N}$ )

$\mathrm{e}=$ error term.

It was hypothesized that the independent variables were not significant factors in the determination of farmers' output level.

\section{Results And Discussion}

Socio-economic characteristics of the respondents

Table 1 indicated that majority (52.50\%) of the respondents fall within the age bracket of 50 years and above.

Table 1: Socio-economic characteristics of the respondents

\begin{tabular}{llll}
\hline Variables & Frequency & Percentage $\mathbf{( \% )}$ & Mean/Mode \\
\hline Age & & & \\
$<20$ & 0 & 0 & \\
$20-29$ & 15 & 12.50 & \\
$30-39$ & 14 & 11.67 & $\mathbf{5 8 . 0 0}$ years \\
$49-49$ & 28 & 23.33 & \\
$50-59$ & 35 & 29.17 & \\
$60 \geq$ & 28 & 23.33 & \\
Total & $\mathbf{1 2 0}$ & $\mathbf{1 0 0}$ &
\end{tabular}




\begin{tabular}{llll} 
Gender & & & \\
Male & 80 & 66.67 & Male \\
Female & 40 & 33.33 & \\
Total & $\mathbf{1 2 0}$ & $\mathbf{1 0 0}$ & \\
Marital Status & & & Married \\
Single & 22 & 18.33 & \\
Married & 90 & 75.00 & \\
Divorced/Separated & 2 & 1.67 & \\
Widowed & 6 & 5.00 & \\
Total & $\mathbf{1 2 0}$ & $\mathbf{1 0 0}$ & \\
Educational Level & & & $\mathbf{8 . 0 0}$ years \\
No Schooling & 46 & 38.33 & \\
Primary School & 25 & 20.83 & \\
Secondary School & 39 & 32.50 & \\
Tertiary Institution & 10 & 8.33 & \\
Total & $\mathbf{1 2 0}$ & $\mathbf{1 0 0}$ & \\
Household Size & & & \\
$1-3$ & 20 & 16.67 & $\mathbf{5 . 0 0}$ persons \\
$4-6$ & 51 & 42.50 & \\
$7-9$ & 44 & 36.67 & \\
$10 \geq$ & 5 & 4.17 & \\
Total & $\mathbf{1 2 0}$ & $\mathbf{1 0 0}$ & \\
\hline Source: Field survey & & & \\
\hline
\end{tabular}

Source: Field survey, 2015.

This implies that water yam cultivation was undertaken mainly by aged farmers above productive age as against younger farmers who may be more interested in cultivation of white yams. Again, majority (66.67\%) of the producers were males while $75 \%$ were married. Household size of 4-6 was dominant representing $42.50 \%$ of the entire household. Literacy level was found to be low among the producers with $38.33 \%$ of them having no formal education. The above finding though contrary to Obinne (2007) and Omojola (2014) who reported high level of educational attainment among yam farmers in southsouth and southeast Nigeria respectively, showed the dwindling popularity of water yam amongst the younger and more educated producers.

\section{Effect of socio-economic factors on the respondents on production output}

Table 2, presents the results of multiple regression analysis of double log function, testing the effect of socio-economic variables: age $\left(\mathrm{X}_{1}\right)$ gender $\left(\mathrm{X}_{2}\right)$, educational level $\left(\mathrm{X}_{3}\right)$, farming experience $\left(\mathrm{X}_{4}\right)$, farm size $\left(\mathrm{X}_{5}\right)$, marital status $\left(\mathrm{X}_{6}\right)$, amount of credit obtained $\left(\mathrm{X}_{7}\right)$, number of extension visits $(\mathrm{X} 8)$ and cost of production inputs $\left(\mathrm{X}_{9}\right)$ on water yam production output. The coefficient of multiple determination $\left(\mathrm{R}^{2}\right)$ of $78.44 \%$ obtained from the analysis implied that $78.44 \%$ variation in the production output of water yam was accounted for by variations in the predictor variables whereas $21.56 \%$ was due to random disturbances. Again, the F-statistics value of 8.90 was also indicative of the overall significant influence of the socio-economic factors on production output while the Durbin-Watson statistic value of 1.72 signifies absence of autocorrelation among observations of the regressors. Among the explanatory variables, age, educational level, gender, farm size, cost of inputs, number of extension visits and amount of credit obtained were found to significantly influence production output. Again, whereas every other variable had positive influence on output, age had a negative influence, implying that the older the water yam farmers the lower their output level. This could be explained by loss of vigour among older yam farmers, which is highly needed for enhanced productivity. This finding is in the line with Oluwatunsin (2011), Rueben and Barau (2012) and Gbegeh and Akubilo (2013), who separately reported negative relationship between age and yam output level in Nigeria. The variables of marital status and farming experience were however statistically not significant at $5 \%$ level.

The coefficient of educational level, gender, amount of credit obtained, farm size and number of extension visit were statistically significant and positively related to production output at 5\% probability level. The implication is that the higher the level of educational attainment, farm size, amount of farm credit obtained and number of extension visits, the higher the output level. The finding is consistent with Nlerum (2006) and Ike and Inoni (2006) who reported positive relationship between level of educational attainment, farm size and extension visits on yam output level in southeast Nigeria.

Table 2: Estimated socio-economic determinants of production output

\begin{tabular}{lll}
\hline Variable & Coefficient & t-statistic \\
\hline Constant & -23319 & -1.09 \\
Age (years) & -7214 & $-0.38^{* *}$ \\
Gender & 181738 & $1.63^{* *}$ \\
Educational Level & 14777 & $2.98^{* *}$ \\
Farming experience & 138.21 & 0.712 \\
Farm size (hectares) & 26641 & $2.01^{* *}$ \\
Marital Status & -32031 & 1.77 \\
Amount of credit obtained (N) & 794.21 & $2.21^{* *}$
\end{tabular}




\begin{tabular}{lll} 
Extension visits & 332.4 & $1.83 * *$ \\
Productive inputs used $(\mathrm{N})$ & 9733 & $2.55^{* *}$ \\
$\mathrm{R}^{2}$ & $78.44 \%$ & \\
$\mathrm{R}^{2}$ (Adjusted) & $73.01 \%$ & \\
F-statistic & 8.90 & \\
Durbin-Watson Statistic & 1.73 & \\
\hline
\end{tabular}

Sources: Computed from field survey data, 2015. Note:** $=$ Significance at 5\% level

\section{Production Systems of Water Yam Farmers}

The production system adopted by water yam farmers, as shown in Table 3, indicated that majority of the farmers (73\%) practiced mixed cropping. Crops planted in association with water yam were maize, cassava, cocoyam and sweet potato. Only a few of them embark on sole cropping. The possible reason for the adoption of mixed cropping by the farmers was to guard against crop failure and ensure food security. The finding is in agreement with Omojola (2014) who reported that intercropping yam with other crops though advantageous in terms of guarding against total crop failure, often reduces yam output and profit margin. Majority $(67.50 \%)$ of the farmers also practice continuous cropping on the same parcel of land. The practice is caused by increased pressure on land and often leads to decline in soil fertility and consequently yield. Majority ( $85 \%$ ) also depended on rainfall as their major source of water thus corroborating, Nlerum (2006) who reported that most arable crop farming in South Eastern Nigeria depended on rainfed agriculture. This has obvious implication on output level as water supply cannot be controlled.

Table 3: Distribution of the farmers according to production (farming) system

\begin{tabular}{|c|c|c|}
\hline Farming System & Frequency & Percentage (\%) \\
\hline \multicolumn{3}{|l|}{ Cropping pattern } \\
\hline Sole Cropping & 30 & 25.00 \\
\hline Mixed cropping & 88 & 73.33 \\
\hline Relay Cropping & 2 & 1.66 \\
\hline Alley Cropping & 0 & 0 \\
\hline Total & 120 & 100 \\
\hline \multicolumn{3}{|l|}{ Rotation System } \\
\hline Continuous Cropping & 81 & 67.50 \\
\hline Crop rotation & 14 & 11.67 \\
\hline Bush Fallowing & 25 & 20.83 \\
\hline Shifting Cultivation & 0 & 0 \\
\hline Total & 120 & 100 \\
\hline \multicolumn{3}{|l|}{ Farm Size } \\
\hline Less than 1 Hectare & 112 & 93.33 \\
\hline $1-5$ hectares & 8 & 6.61 \\
\hline Greater than 5 hectares & 0 & 0 \\
\hline Total & 120 & 100 \\
\hline \multicolumn{3}{|l|}{ Source of Water } \\
\hline Rainfed farming & 102 & 85.00 \\
\hline Irrigation Only & 0 & 0 \\
\hline Rainfed with irrigation & 18 & 15.00 \\
\hline Total & 120 & 100 \\
\hline \multicolumn{3}{|l|}{ Variety grown } \\
\hline Local variety & 115 & 95.83 \\
\hline Improved (hybrid) variety & 5 & 4.17 \\
\hline Genetically modified variety & 0 & 0 \\
\hline Total & 120 & 100 \\
\hline \multicolumn{3}{|l|}{ Method of Land Preparation } \\
\hline Human Labour & 110 & 91.67 \\
\hline Animal Drawn Implements & 10 & 8.33 \\
\hline Tractor & 0 & 0 \\
\hline Total & 120 & 100 \\
\hline \multicolumn{3}{|l|}{ System of Pest/Disease Control } \\
\hline Cultural/Manual & 81 & 67.50 \\
\hline Agro-Chemicals & 39 & 32.50 \\
\hline Genetic Modified Cultivars & 0 & 0 \\
\hline Total & 120 & 100 \\
\hline
\end{tabular}

Sources: Field Survey, 2015.

Again, majority (67.5\%) of the respondents also indicated using cultural method of pest and disease control. Though the use of pesticides was fast gaining ground as shown in the score of $32.5 \%$, the adoption of genetically improved species with inert resistance to pests and diseases still remained very low.

Most of the respondents (93\%) also reported cultivating less than one hectare of water yam using local implements such as hoes and matchets. This often led to low productivity and profitability. The level of mechanization was also found to be too low to encourage increased production. This finding is in line with Awoniyi and Omonona (2006) who reported low output level among water yam farmers in EkitiState with 
average farm holding of less than one hectare. The findings also revealed that majority (96\%) of the respondents planted local varieties with low yield potentials, while the remaining $4 \%$ cultivated improved and hybrid varieties obtained from research institutes. The implication of use of local water yam varieties by farmers is manifested in the low yield and poor tuber quality. Fasisi (2006) reported a significant yield differentia among water yam farmers using improved and local cultivars in Ondo State of Nigeria. Moreover, the use of genetically modified species with high yield potentials was found to be alien to the producers.

\section{Profitability of Water yam Production}

Profitability of water yam production was determined using net farm income analysis as shown in Table 4. The findings indicated that total revenue realized by the producers was $\mathrm{N} 6,105,804$ while total cost amounted to $\$ 4,399,839$. Total variable cost amounted to $\$ 4,212,690$ representing $95 \%$ of total cost while fixed cost (depreciation on fixed inputs) accounted for only $5 \%$ of total cost. Cost of labour was the highest cost item representing $43.7 \%$ of total cost followed by cost of planting materials (seed yams). Water yam producers realized gross margin, net farm income and mean net farm income of $\$ 1,893,114, \$ 1,705,965$ and $\$ 14,216.38$ respectively. Net return on investment was 0.39 indicating that the sum of $\$ 0.39$, was returned as income for every $\$$ linvested in production. The findings were consistent with Ani, Irokaa and Ogebe (2015) who reported a mean gross margin of $\$ 35,500$ for farmers growing white yams and water yams in Ukum L.G.A of Benue State. The low net return on investment of 0.39 could be as a result of low price of water yam tubers in the market caused by its poor acceptability. This view was in line with Ayanwuyi, Akinboye and Oyetoro (2011) who reported that the loose and watery texture of most water yams makes them unsuitable for preparation of fufu and as such unacceptable to the people.

Table 4: Estimated profit from water yam production

\begin{tabular}{lrr}
\hline Revenue/Cost & Amount (N) & Percent \\
\hline Total Revenue (TR) & $6,105,804$ & \\
Variable Cost & $1,050,450$ & 23.9 \\
Seed yams & $1,922,357$ & 43.7 \\
Labour & 535,118 & 12.2 \\
Fertilizer & 171,00 & 3.9 \\
Agro-chemicals & 280,990 & 6.4 \\
Transportation & 252,775 & 5.7 \\
Storage & $4,212,690$ & 95.7 \\
Total variable cost (TVC) & & \\
Fixed Cost & 63,820 & 1.5 \\
Depreciation on hoes & 57,100 & 1.3 \\
Depreciation on matchet & 39,807 & 0.9 \\
Depreciation on wheel barrow & 26,414 & 0.6 \\
Depreciation on spraying machine & 187,149 & 4.3 \\
Total Fixed Cost (TFC) & $4,399,839$ & \\
Total Cost (TC=TVC+TFC) & $1,893,114$ & \\
Gross margin (GM=TR-TVC) & $1,705,965$ & \\
Net Farm Income (NFI=TR-TC) & $14,216.38$ & \\
Mean Net farm Income & & \\
(MNFI = Net Farm income & 0.39 & \\
Net Return on Investment & & \\
\hline
\end{tabular}

Source: Field Survey, 2015

\section{Constraints to Water Yam Production}

Production of water yam in southeast Nigeria was constrained by factors ranging from high cost of production to poor price of produce. As shown in Table 5, high cost of production, particularly labour cost was the prime production constraint with mean value of 3.81 on a four (4) point scale. The major reason for the high labour cost was the scarcity of farm labourers in the area occasioned by the rural-urban drift of able bodied young men and women in search of white collar jobs. Gbegeh and Akubilo (2013) and Omojola (2014) identified the problem of high labour cost as a major limitation to increased yam production.

Table 5: Distribution of respondents according to constraints to water yam production

\begin{tabular}{lll}
\hline Constraints & Mean score & Rank \\
\hline High cost of labour & 3.81 & $1^{\text {st }}$ \\
Low acceptability of tuber & 3.75 & $2^{\text {nd }}$ \\
Poor pricing & 3.71 & $3^{\text {rd }}$ \\
Dearth of capital & 3.50 & $4^{\text {th }}$ \\
Inadequacy of improved varieties & 3.49 & $5^{\text {th }}$ \\
Poor of knowledge of improved techniques & 3.30 & $6^{\text {th }}$ \\
Low level of mechanization & 3.21 & $7^{\text {th }}$ \\
Dearth of processing and storage facilities & 2.86 & $8^{\text {th }}$ \\
Scarcity of land & 1.23 & $9^{\text {th }}$ \\
\hline
\end{tabular}

Source: Field survey, 2015. Note: Multiple responses recorded. 
Low acceptability as well as poor pricing of water yam tubers with means of 3.75 and 3.71 were also identified as major constraints to enhanced production level. This was caused by consumers preference of white yam to water yam because of the poor texture and taste of local water yam varieties. Incidentally, some of the improved water yam varieties with high quality attributes developed by research institutes in the country are yet to be accessed by the farmers. The fourth major production constraint was inadequate capital. With mean score of 3.50, inadequate of capital constitutes a serious limitation to production amongst the resource poor rural farmers. The problem was further complicated by the inaccessibility of the farmers to formal loan sources due to lack of collaterals. Ugwumba and Omojola (2012) and Ugwu (2013) corroborated the finding, stating that inadequate capital poses serious production constraint to arable crop farming in Nigeria. Other serious production constraints include scarcity of high yielding improved varieties (3.41), poor knowledge of improved production techniques (3.30), poor level of mechanization (3.21), dearth of processing and storage facilities (2.86). Scarcity of land (1.23) was however not considered as major limitations to enhanced water yam production in the area. Ike and Inoni (2006) reported that inadequacy of land was not considered as major problem by small scale yam producers in southeast Nigeria.

\section{Conclusion And Recommendations}

The production level of water yam in southeast Nigeria was influenced by factors of gender, age of farmers, educational level, farm size, cost of inputs, extension visits among others. The production system used by the farmers was traditional and contributed to the dwindling output. The enterprise was profitable though with low return on investment. Water yam production in the area was constrained by high labour cost, scarcity of improved varieties, poor acceptability of the local varieties, dearth of modern technologies among others.

It was recommended that research and extension institutes should intensify efforts at developing and disseminating better quality water yam varieties that will be more acceptable to the people. Government should also assist water yam producers through subsidization of cost of modern farm inputs and provision of soft credits, to enhance their productivity and profitability.

\section{References}

[1] All Nigerian Recipes (n.d). Common recipes made from water yam. Retrieved from http://www.allnigerianrecipes.com/foodingredients/yam.html.

[2] Fasasi, A. R. (2006). Resource use efficiency in yam production in Ondo State, Nigeria Agricultural Journal, 1(2), 36-40.

[3] Gbegeh, B. D., \& Akubuilo, C. J. C. (2013).Socio-economic determinants of adoption of yam minisett by farmers in Rivers State, Nigeria. Journal of Agricultural Research, 2 (1), $33-36$.

[4] Ike, P. C., \& Inoni, O. E. (2006).Determinants of yam production and economic efficiency among small holder farmers in SouthEastern Nigeria. Journal of Central European Agriculture, 7(2), 337-342.

[5] National Agricultural Extension and Research Liaison Services (NAERLS) \& Federal Department of Agricultural Extension (FDAE, 2014).Agricultural Performance survey report of 2013 wet season in Nigeria. Zaria, Nigeria: NAERLS press.

[6] Nlerum, F. E. (2006). Socio-economic characteristics as correlates of adoption among yam farmers in rural Ikwerre area of Rivers State, Nigeria. Journal of Agricultural Extension, 2 (2), $74-80$.

[7] Obinne, K. (2007). Profitability and resource use efficiency of seed yam (Dioscorea rotundata, poir) production from minisett in north agro-ecological zone of Delta State Nigeria. M.Sc thesis, Delta State University, Abraka, Nigeria.

[8] Oluwatusin, F. M. (2011). Measuring technical efficiency of yam farmers in Nigeria: A stochastic parametric approach. Agricultural Journals, 4 (2), 40-46.

[9] Omojola,J.T.(2014).Economic efficiency and profitability of yam production in South Western Nigeria. Ph.D, Thesis Anambra State University, Igbariam Campus, Anambra State, Nigeria.

[10] Oselobe, H.O., \& Okperie, E.O. (2008).Evaluation of water yam (D. alata) genotypes for yield and yield components in Abakaliki agro-ecological zone of Nigeria. Journal of Tropical Agriculture, Food, Environment and Extension,7(3), 117-122.

[11] Ugwumba, C. O. A., \& Omojola, J. T. (2012).Socio-economic determinants and profitability of yam production in Ipao-Ekiti, Nigeria. Journal of Sciences and Multidisciplinary Research, 4 (2), $96-103$.

[12] Wireko-manu, F.D., Ibok, O., Elis, W.O., Asiedu, R., \& Maziya-Dixon, B. (2013). Potential health benefits of water yam (D.alata). Pubfacts Scientific Publication Data. Retrieved from http://www.pubfacts.com/detail/24056383.

Nwike M. C. "Economics of Water Yam (Dioscorea alata) Production in South Eastern Nigeria." IOSR Journal of Agriculture and Veterinary Science (IOSR-JAVS) 10.7 (2017): 13-18. 